\title{
ANAEROBIC TREATMENT OF OLIVE MILLS WASTE: POTENTIALS FOR WATERSHED PROTECTION IN JORDAN
}

\author{
Nidal Mahmoud \\ Institute of Environmental and Water Studies (IEWS), Birzeit University, P.O. \\ Box 14, Birzeit, the West Bank, Palestine
}

Adriaan Mels

Lettinga Associates Foundation (LeAF), PO Box 500, 6700, AM Wageningen,

The Netherlands

Jules B. van Lier

Section Sanitary Engineering, Department of Water Management, Faculty of Civil Engineering and Geosciences, Delft University of Technology, Delft, The

Netherlands

\begin{abstract}
Jordan watersheds heavily suffer from the seasonal discharge of highly concentrated olive mill wastewater (OMW). Environmental concern and protection of the scarcely available water resources calls for adequate treatment of OMW prior to discharge. This paper describes an inventory that was made with the aim of developing pollution prevention strategies for the olive mill sector of the Jerash Governorate in Jordan. Emphasis was given to compiling regional research which shows that modern anaerobic technology may play an important role in treating the highly concentrated OMW. The paper also presents pre and post treatment options for achieving local discharge criteria. Based on literature review and current insights three innovative treatment strategies are presented for OMW in the Jerash region.
\end{abstract}

\section{KEYWORDS}

Anaerobic treatment; olive mill wastewater; UASB; watershed protection; sustainable development; treatment strategy.

\section{INTRODUCTION}

Olive mill wastes are increasingly recognised as one of the most serious environmental threats in the Mediterranean region, where almost the entire world's production of olive oil is located [1-3]. It is estimated that around 30 million cubic meter of olive mill wastewater (OMW) is generated annually in the Mediterranean area, during the seasonal extraction of olive oil [4-6]. The discharge of high loads of organic pollutants, nutrients and polyphenolic components to surface and ground water raises concerns about possible negative effects of OMW discharge on the environment [6]. Proper treatment and disposal of OMW is presently high on the agenda in the Mediterranean countries, such as Spain, Italy, Greece, and Tunisia as well as in Jordan, the focus country of this study. 
In Jordan, which is a (semi-)arid country, water resources are scarce and traditional water supply resources are being stretched to their maximum limits. Therefore, protection of water resources from pollution is a vital issue to achieve sustainable development. The Jordan valley and its tributaries are the most potential areas for development, especially in the field of agriculture. However, the natural resources, e.g. surface and groundwater, of the Jordan River basin are threatened by weak management. Therefore, severe deterioration of these resources is expected on the mid-long term if no appropriate measures are taken.

OMW is one of the most severe polluting streams affecting the Jordan Valley watershed. In Jordan, the area planted with olive trees has increased significantly from 285 million $\mathrm{m}^{2}$ in 1984 [7] to 644.8 million $\mathrm{m}^{2}$ in the year 2002. In the year 2000 , olive trees formed $73 \%$ of total area planted with fruit trees in Jordan [8]. More than $13 \%$ of the total number of olive trees (8.57 million trees) is found in Jerash Governorate, located in the northern parts of Jordan. For treating the concentrated OMW, the paper discusses the potential role of modern anaerobic high-rate systems like the upflow anaerobic sludge blanket (UASB) system, emphasizing its advantages and limitations. Flow-schemes of three strategies are proposed for on-site treatment of OMW for reaching Jordanian discharge standards. The research was performed in Al-Merad, Burma and Al-Mastaba watershed areas in Jerash and was accomplished by means of interviews with local stake holders, field visits and literature search.

\section{TREATMENT AND DISPOSAL OF OMW}

\subsection{Anaerobic treatment}

Practically all treatment processes developed for domestic and industrial wastewaters have been tested more or less successfully on OMW. The most feasible of these processes is the anaerobic treatment of OMW that has the advantage of producing energy in the form of methane instead of consuming energy [1,2]. Anaerobic treatment is particularly of interest for OMW because of its high organic strength and its seasonal production. The process can handle high organic loading rates. The excess sludge production is significantly lower than in the aerobic processes. The process also has low nutrients requirement, a feature that is particularly important for treating wastewaters like OMW that have relatively low nitrogen content, while the COD is high. The low decay rates of the anaerobic bacteria allow the process to carry out seasonal operations at campaign industries without continuous feed requirement $[1,9,10]$. Anaerobic treatment may function as a pre-treatment or even as an alternative to aerobic treatment. The construction and operation of anaerobic wastewater treatment systems is rather simple and cheap. The UASB reactor is recommended for the treatment of agro-industrial wastewaters compared to other anaerobic systems, as it can tolerate higher organic loading rates $[2,11]$.

\subsection{Nutrients requirements in anaerobic treatment of OMW}

Many researchers have pointed at the imbalance in the COD:N ratio in OMW for biological wastewater treatment [2, 12, 13]. For anaerobic treatment, the required nitrogen and phosphorous concentration is distinctly lower than in the case of aerobic treatment, because under anaerobic conditions the sludge yield is much less.

The nutrient requirement for systems treating acidified wastewaters equals more or less COD:N:P of 1000:5:1, while for non-acidified wastewater this ratio equals 350:5:1. For partly 
acidified wastewater the required ratio is between these values. To resolve potential nutrient deficiency, OMW is often diluted with domestic sewage prior to biological treatment. In principle, the nutrients available in the domestic sewage would also be sufficient for a wellfunctioning anaerobic treatment. Typical characteristics of olive mill wastewater are presented in Table 1.

\subsection{Treatment in UASB reactors}

Various researchers showed that, in order to treat raw OMW with a UASB reactor, it requires considerable dilution with water, viz. four to five times [1, 2, 12, 14]. Dilution and appropriate mixing is of particular importance during the start up, because else the process will become very unstable. Most likely, this problem can be attributed to inhibition by phenolic compounds and in particular to the lower molecular weight ones [9, 15]. It has been reported that phenol concentration up to a range of $500-700 \mathrm{mg} / \mathrm{L}$ is generally not inhibitory to the UASB process [16]. Since phenol is anaerobically degradable, the phenol concentration in the bulk solution of the reactor might drop to low levels, particularly after several months of sludge adaptation $[17,18]$.

Table 1. Characteristics of OMW in Jordan in comparison to Jordanian standards and regulations for the discharge and reuse of industrial wastewater.

\begin{tabular}{|c|c|c|c|c|c|}
\hline \multirow[b]{2}{*}{ Parameter } & \multirow[b]{2}{*}{ Units } & & \multicolumn{3}{|c|}{ Maximum Allowable Limit } \\
\hline & & $\begin{array}{c}\text { Average } \\
\text { characteristics } \\
\text { of OMW }\end{array}$ & $\begin{array}{l}\text { Disposal to } \\
\text { Wadis \& } \\
\text { Rivers }\end{array}$ & $\begin{array}{l}\text { Reuse for } \\
\text { Irrigation }\end{array}$ & $\begin{array}{c}\text { Discharge to } \\
\text { Sanitary Sewer } \\
\text { System }\end{array}$ \\
\hline $\mathrm{pH}$ & & 5.67 & $6.5-9.0$ & $6.5-8.4$ & $5.5-9.5$ \\
\hline $\mathrm{EC}$ & $\mu \mathrm{s} / \mathrm{cm}$ & 9,350 & & & \\
\hline TDS & $\mathrm{mg} / \mathrm{L}$ & 39,133 & 3000 & 2000 & \\
\hline TSS & $\mathrm{mg} / \mathrm{L}$ & 29,313 & 50 & 1000 & 1100 \\
\hline TVSS & $\mathrm{mg} / \mathrm{L}$ & 22,844 & & & \\
\hline TFSS & $\mathrm{mg} / \mathrm{L}$ & 6,232 & & & \\
\hline COD & $\mathrm{mg} / \mathrm{L}$ & 117,105 & $150^{+}$ & - & 2100 \\
\hline $\mathrm{BOD}_{5}$ & $\mathrm{mg} / \mathrm{L}$ & 38,048 & $50^{+}$ & - & 800 \\
\hline FOG & $\mathrm{mg} / \mathrm{L}$ & 6,983 & 5 & 5 & 50 \\
\hline T-P & $\mathrm{mg} / \mathrm{L}$ & 272 & & - & \\
\hline $\mathrm{NH}_{4}-\mathrm{N}$ & $\mathrm{mg} / \mathrm{L}$ & 45 & & - & \\
\hline TKj-N & $\mathrm{mg} / \mathrm{L}$ & 704 & & 50 & \\
\hline $\mathrm{Na}$ & $\mathrm{mg} / \mathrm{L}$ & 258 & & - & \\
\hline $\mathrm{Ca}$ & $\mathrm{mg} / \mathrm{L}$ & 420 & & & \\
\hline $\mathrm{Mg}$ & $\mathrm{mg} / \mathrm{L}$ & 52 & & & \\
\hline $\mathrm{K}$ & $\mathrm{mg} / \mathrm{L}$ & 3,599 & & & \\
\hline $\mathrm{Cl}$ & $\mathrm{mg} / \mathrm{L}$ & 734 & 500 & 350 & \\
\hline $\mathrm{HCO}_{3}$ & $\mathrm{mg} / \mathrm{L}$ & 3,086 & - & 500 & \\
\hline Phenol & $\mathrm{mg} / \mathrm{L}$ & 3,402 & 0.002 & 0.002 & 10 \\
\hline
\end{tabular}

Sources: [7]; ${ }^{+}$Monthly average; - Undetermined

Sabbah et al. [19] showed that the methanogenic activity of the seed sludge is an important parameter in reducing the start up period to obtain maximum performance. 
Research into the operational conditions of UASB reactors for treating OMW was done a.o. in Jordan by operating a UASB reactor at $37{ }^{\circ} \mathrm{C}$ seeded with digested sewage sludge and fed with OMW. Before treatment, the OMW was adjusted to $\mathrm{pH} 7-8$, preventing acidification of the reactor [7]. During start-up the reactor was operated at 6 days hydraulic retention time (HRT), a sludge concentration of $10 \mathrm{~g}$ volatile suspended solids (VSS)/L and fed with diluted OMW $(\sim 1500 \mathrm{mg} \mathrm{COD} / \mathrm{L})$ at $0.3 \mathrm{kgCOD} / \mathrm{m}^{3} . \mathrm{d}$. The influent COD was gradually increased from around $1500 \mathrm{mg} \mathrm{COD} / \mathrm{L}$ to around $30,000 \mathrm{mg} \mathrm{COD} / \mathrm{L}$, at a constant HRT of 4 days. The effluent COD was stable in the range $4000-5000 \mathrm{mg} \mathrm{COD} / \mathrm{L}$, over the operational period of 425 days when the influent COD and organic loading rate (OLR) were around 28,000 mg/L and $7.5 \mathrm{kgCOD} / \mathrm{m}^{3} . \mathrm{d}$, respectively. When the influent $\mathrm{COD}$ concentration was further increased to around $30,000 \mathrm{mg} \mathrm{COD} / \mathrm{L}$, the effluent quality deteriorated as effluent COD went up from approximately $4000 \mathrm{mg} \mathrm{COD} / \mathrm{L}$ to $10000-12000 \mathrm{mg} \mathrm{COD} / \mathrm{L}$.

Similarly, Sabbah et al. [20] treated OMW in a UASB reactor operated at a constant HRT of 5 days, a temperature of $35{ }^{\circ} \mathrm{C}, \mathrm{pH} 7$, and applied a step-wise increased influent COD concentration. They found COD removal efficiencies in the range of $70-90 \%$ when imposing an OLR of 1-5 gCOD/L.d. When the OLR was increased beyond $8 \mathrm{~g} / \mathrm{L} . \mathrm{d}$, a decrease in the COD removal efficiency to $50 \%$ was found.

The successful application of either a single stage anaerobic treatment or a combined anaerobic /aerobic treatment for OMW treatment to comply with the Jordanian standards in terms of COD is dependent on the applied loading rates. Research by RSS [7] showed that if a low influent concentration with a relatively long retention time was applied, anaerobic treatment using UASB reactors was appropriate for direct discharge of the treated wastewater to the sewer network. The operational conditions were: HRT $=3$ days, OLR $=4 \mathrm{gCOD} / 1$.day and influent COD $=13,000 \mathrm{mg} / \mathrm{L}$. Nevertheless, it can be seen from the results of other pilot plant studies that the phenol concentration in the UASB reactors effluents had never achieved the imposed effluent phenol concentration of $10 \mathrm{mg} / \mathrm{L}$ set by the Jordanian standards [7]. This shows that post treatment and/or pre treatment, i.e., aerobic and/ or physical-chemical treatment, is likely necessary.

\section{4 (Pre)-treatment to remove polyphenolic components}

Anaerobic methanogenic bacteria are sensitive to the high phenolic concentrations found in OMW which may result in process inhibition [21]. As was already discussed, this can especially be a problem at start-up, when the biological activity is still relatively low. In those cases a pre-treatment step could be applied, consisting of physical-chemical or biological steps that are capable of decreasing the toxicity of phenolic compounds.

Tay et al. [22] demonstrated that aerobic granules can be developed with high phenol conversion rates in a sequencing batch reactor treating synthetic wastewater. The aerobic granules first appeared on day 9 after the start up, quickly grew and remained stable even at the maximum phenol concentration tested of $2.5 \mathrm{~kg}$ phenol $/ \mathrm{m}^{3} . \mathrm{d}$. At this high loading rate, phenol was completely degraded and a high biomass concentration was maintained in the reactor even at influent phenol concentrations of $1900 \mathrm{mg} / \mathrm{L}$. However, the appearance of granular biomass in an aerobic SBR pre-treating OMW effluent is rather questionable. The high COD strength and the high suspended solids concentration in OMW shortens the required long solids retention time generally needed for sludge granulation. Moreover, the presence of solids can even hamper the granules growth [23]. Alternatively, upfront dilution can be implemented in which aerobically post-treated effluents are recirculated to dilute the incoming wastewater [24]. During post treatment phenolic compounds are auto-oxidised or degraded after which the methanogenic toxicity is decreased. Instead of pre-treatment, the aerobic SBR system could offer a cost effective post-treatment alternative. 
Several authors have shown that fungi species such as Phanerochaete chrysosporium, Coriolopsis polyzona, Trametes versicolor, Pycnoporus cinnabarinus can significantly reduce the colour of OMW by depolymerization of a wide range of mono-aromatics, e.g. phenolic compounds [25, 26]. Dhouib et al. [27] tested a pilot-scale fungal pre-treatment of raw OMW using $P$. chrysosporium followed by anaerobic digestion, without any addition of nutrients or alkalinity. Ultrafiltration was assayed as a post-treatment for complete detoxification and colour removal allowing water recovery and reuse for agricultural purposes. P. chrysosporium DSM 6909 was cultivated on OMW in an air lift reactor (ALR) at an HRT of 3- 5 days. The effluent of this pre-treatment reactor was fed into an anaerobic filter after a sedimentation step. The anaerobic filter was continuously operated for 6 months at loading rates reaching 8 g/L.d without any apparent toxicity. The $P$. chrysosporium DSM 6909 decreased the relative toxicity assessed according to ISO $11348-2$ (ISO 11348,1998 ) from $100 \%$ to $74 \%$.

Sabbah et al. [20] showed a high removal capacity of a physical-chemical treatment system for phenolic compounds during the treatment of undiluted raw OMW with COD $=148,000$ $\mathrm{mg} / \mathrm{L}$ and; phenols $=2,210 \mathrm{mg} / \mathrm{L}$. The system consisted of a multi-layered sand filter and subsequent treatment by powder activated carbon (PAC) at a $10 \mathrm{~g}$ of activated carbon added to $1 \mathrm{~L}$ of OMW. The concentration of phenols was reduced from $2,210 \mathrm{mg} / \mathrm{L}$ to $285 \mathrm{mg} / \mathrm{L}$ after sand filtration and to $108 \mathrm{mg} / \mathrm{L}$ after the activated carbon step, viz. an overall removal of $95 \%$ of the poly-phenolic compounds. Although this is still far higher than the Jordanian standard requirement of $10 \mathrm{mg} / \mathrm{L}$, the process shows interesting perspectives for post treating the UASB-reactor effluent. Similarly, Al-Malah et al. [28] showed that treatment of OMW with activated clay removed about $81 \%$ of the poly-phenols present in OMW.

\subsection{Post treatment of UASB-treated OMW}

The results of Dhouib et al. [27] showed that the integrated aerobic ( $P$. chrysosporium) anaerobic process reduced the $\mathrm{BOD}_{5}, \mathrm{COD}$ and total polyphenols from respectively $34.4,117$ and $9.2 \mathrm{~g} / \mathrm{L}$ to $4.5,21.9$ and $1.578 \mathrm{~g} / \mathrm{L}$. Those effluent concentrations values by far exceeded the Jordanian standards for direct discharge to a sewer network or a natural water body, and also the Tunisians which requires a COD concentration of less than $0.09 \mathrm{~g} / \mathrm{L}$. The experiments also showed that the residual COD was poorly biodegradable $\left(\mathrm{COD} / \mathrm{BOD}_{5}=4.87\right)$. To go to even lower effluent COD values, they investigated the removal of the residual black colour by ultrafiltration (UF). The determination of the physical-chemical parameters of the ultrafiltered anaerobic effluent showed that the $25 \mathrm{KDa}$ cut-off membranes was able to remove $100 \%$ of the suspended solids, $95 \%$ of the colour and $45 \%$ of the residual COD. Moreover, the results showed that the UF membrane retained high polyphenolic compounds as well as residual mono-aromatic compounds. Unfortunately, the effluent phenolic compounds concentration was not reported explicitly. Apparently, UF could be an option of interest which needs to be researched further.

\section{SUGGESTIONS FOR POLLUTION PREVENTION STRATEGIES FOR THE JERASH GOVERNORATE}

Based on the reviewed articles this section presents a number of pollution prevention strategies for the Jerash governorate, including three innovative treatment strategies for treating OMW of small to medium-size olive mills in the Jerash region.

Cost-effective treatment of OMW with anaerobic technologies like UASB reactors is considered a core technology of the treatment scheme. Decentralised treatment is an attractive option, both technically (to avoid problems with sewers) and financially (less costs for 
vacuum transport). Treated effluents should preferably comply with irrigation standards considering the water scarcity in the region.

As discussed earlier, phenolic compounds are the bottleneck of OMW treatment and disposal. The research discussed so far reveals that some researchers tried to reduce the phenolic compounds prior to anaerobic treatment to reduce toxicity. Consequently, high organic loading rates can be imposing to the anaerobic step, while achieving a more stable process. The problem with the use of fungi as suggested by Dhouib et al. [27] would be the high oxygen need for biological reactions. The other problem is that it is difficult to operate a continuous flow fungi reactor. Other researchers investigated the removal of phenolic compounds from the final effluent by physical-chemical processes like sand filtration followed by activated carbon [20].

Based on available information and data, three decentralised treatment strategies (1,2 and 3) are proposed to be tested at pilot scale for treating OMW for small to medium size olive mills. The final choice of the best scenario will depend on the technical performance as well as the cost.

\subsection{Strategy 1}

Treatment strategy 1, presented in Figure 1, is based on diluting the raw OMW with secondary treated municipal wastewater effluent for nutrients provision. The type of dilution water, i.e. water or treated effluent, should be verified to assess the actual need for nutrients. The OMW dilution is aimed at reducing the impact of the toxic compounds. It is advisable to adjust the $\mathrm{pH}$ of the influent OMW to 7-8 in the start-up period of the anaerobic. During longterm operation, the alkalinity demand largely can be obtained from the reactor effluent. Afterwards, the anaerobically pre-treated effluent should be post-treated to achieve effluent discharge requirements and preferably irrigations standards (COD, phenol, etc) by means of a physical process, viz. sand filtration-PAC and/or UF, and aerobic granulated sludge bioreactor. In the case those effluent requirements have not been achieved, then a combination of the various post treatment process might be assessed as illustrated by the dashed lines. This solution can only be of interest if afterwards the water is used for irrigation since dilution cannot be the solution for pollution, but could be of interest if the water is anyway needed. 




Figure 1. Processes scheme of proposed strategy 1 for OMW treatment in order to comply with the Jordanian requirements for industrial wastewater discharge. The dashed lines present alternative treatment lines which might be examined if the main flow scheme presented by the solids line is not satisfactory to comply with the discharge requirements.

\subsection{Strategy 2}

Treatment strategy 2 presented in Figure 2 is based on upfront dilution. This treatment strategy basically is similar to treatment strategy 1 , but instead of applying external water source, treated effluent will be re-circulated for raw OMW dilution. The alkalinity in the recirculated effluent might suffice for raw OMW conditioning prior to the biological wastewater treatment systems, meanwhile phenolic compounds are reduced to below inhibitory levels. 


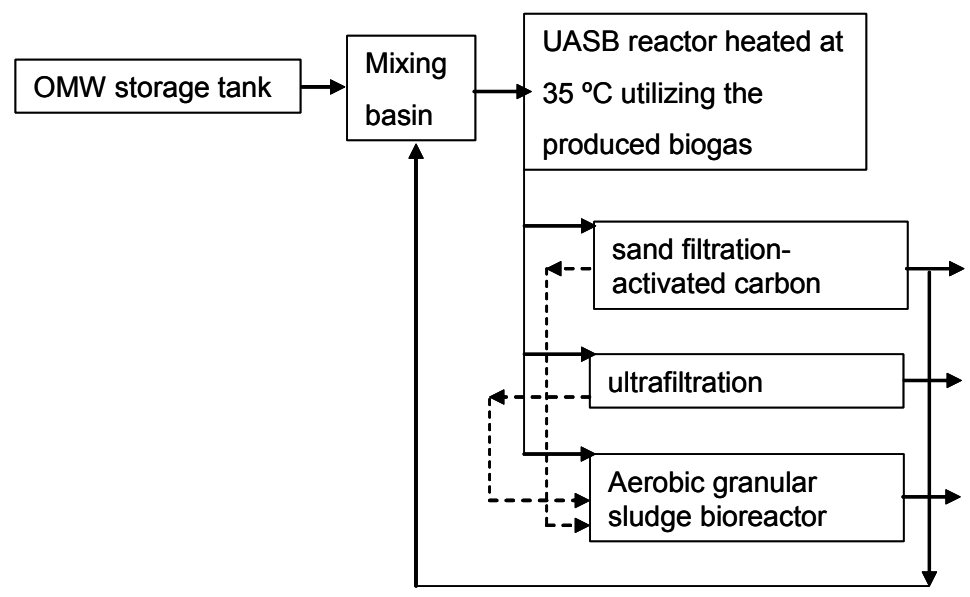

Figure 2. Processes scheme of proposed strategy 2 for OMW treatment in order to comply with the Jordanian requirements for industrial wastewater discharge. The dashed lines present alternative treatment lines which might be examined if the main flow scheme presented by the solids line is not satisfactory to comply with the discharge requirements.

\subsection{Strategy 3}

Strategy 3 presented in Figure 3 includes a fungi based bioreactor that has been partly tested by Dhouib et al. [27]. However, at this stage a fungi reactor cannot be considered as proven while the combination of technologies needs optimisation. The points of concern are the development (growth and retention) of fungi in the aerobic bioreactor, the workability of the system in practice (operational problems) and the proper conditions for operating and combining the biological units and the physical-chemical units (UF and the sand- PAC filtration unit).

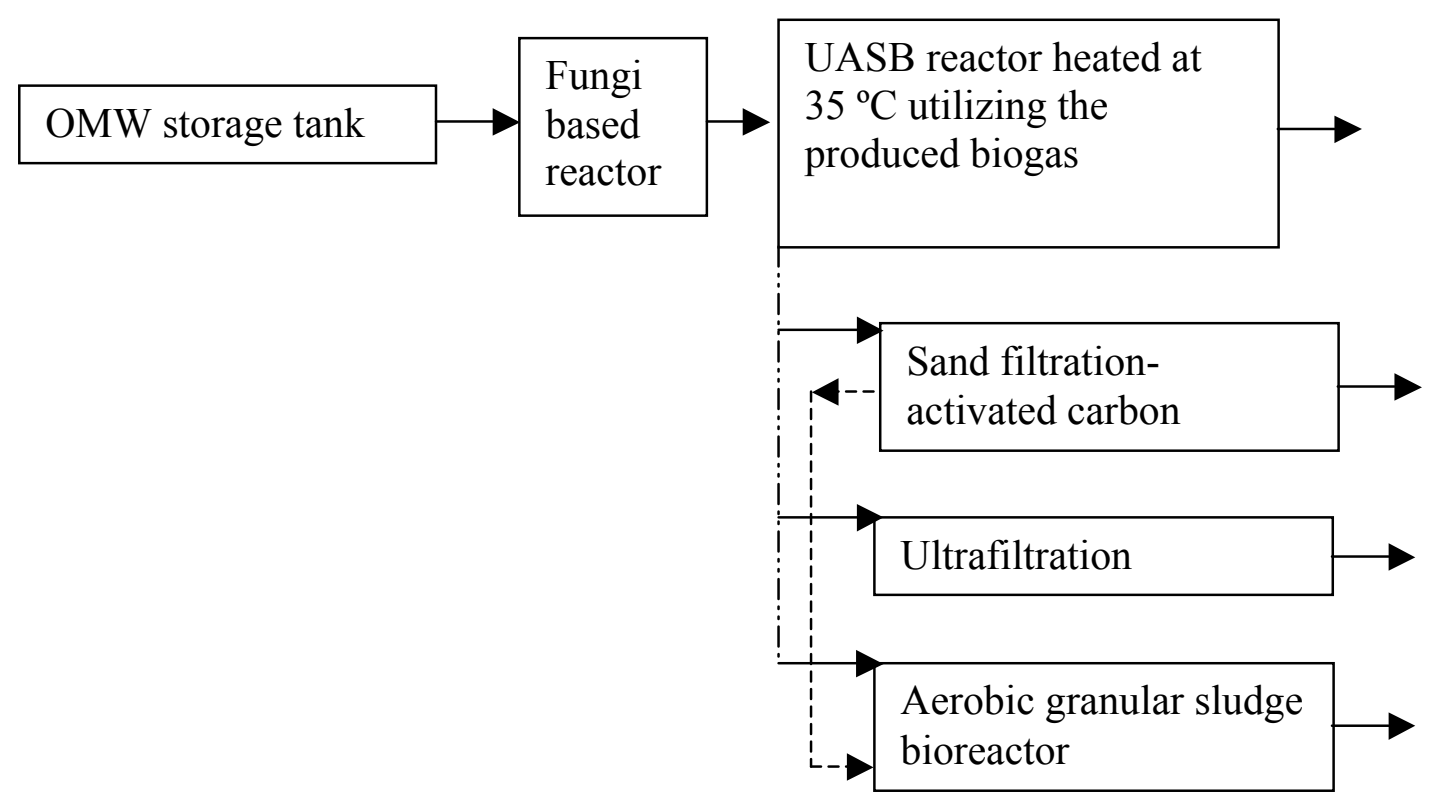

Figure 3. Processes scheme of proposed strategy 3 for OMW treatment in order to comply with the Jordanian requirements for industrial wastewater discharge. The dashed lines present alternative treatment lines which might be examined if the main flow scheme presented by the solids line is not satisfactory to comply with the discharge requirements. 


\section{CONCLUSIONS AND RECOMMENDATIONS}

1. Anaerobic OMW treatment in a UASB reactor at $35^{\circ} \mathrm{C}$ is technically feasible and results in COD removal efficiencies of $70-80 \%$.

2. So far, successful mesophilic anaerobic treatment of OMW is based on prior dilution with a factor four to five, for reducing phenol concentrations and achieving final influent concentrations of about $20,000 \mathrm{mg} \mathrm{COD} / \mathrm{L}$. The UASB reactor should be operated at an HRT of $3-5$ days and organic loading rates of $4.5-6 \mathrm{kgCOD} / \mathrm{m}^{3} . \mathrm{d}$. Those operational conditions will achieve a COD effluent concentration that is acceptable for disposal in the sewer system according to Jordanian standards.

3. Various pilot plant studies showed that the imposed effluent phenol concentration of $10 \mathrm{mg} / \mathrm{L}$ by the Jordanian standards for the discharge of industrial wastewater to sanitary sewer system was never achieved by anaerobic reactor alone. Therefore some form of pre and/or post treatment processes (aerobic, physic-chemical) will be required. Post treatment also becomes essential when high organic loading rates are applied or when the treated OMW are to be discharged directly to the environment or to be reused in agriculture.

4. Dilution of the raw OMW with settled sewage or secondary municipal effluent is recommended with vigilance to provide the possible lacking nutrients.

5. It is recommended to practically testing the performance of the presented three possible treatment strategies based on anaerobic treatment of OMW and complemented by various pre- and post treatment strategies at various operational conditions.

\section{REFERENCES}

[1] Dalis, D., Anagnostidis, K., Lopez, A., Letsiou, I., Hartmann, L., 1996. Anaerobic digestion of total raw olive-oil wastewater in a two-stage pilot-plant (up-flow and fixedbed bioreactors). Bioresource and Technology, 57, 237-243.

[2] Rozzi, A., Malpei, F., 1996. Treatment and disposal of olive mill effluents. International Biodeterioration and Biodegradation, 135-144.

[3] Benitez, F. J., Beltran-Heredia, J., Torregrosa, J., Acero, J. L., 1997. Aerobic degradation of olive mill wastewater. Applied Microbiology and Biotechnology, 47, 185-188.

[4] Beccari, M., Bonemazzi, E., Majone, M., Riccardi, C., 1996. Interactions between acidogenesis and methanogenesis in the anaerobic treatment of olive mill effluents. Water Research, 30, 183-189.

[5] Casa, R., D’Annibale, A., Pieruccetti, F., Stazi, S. R., Sermani, G., Lo Cascio, B., 2003. Reduction of the phenolic components in olive-mill wastewaters by an enzymatic treatment and its impact on durum wheat (Triticum durum Desf.) germinability. Chemosphere, 50, 959-966.

[6] Adhoum, N., Monser, L., 2004. Decolourization and removal of phenolic compounds from olive mill wastewater by electrocoagulation. Chemical Engineering and Processing, 43, 1281-1287.

[7] RSS, 1997. Wastewater from olive mills: reducing environmental impacts (Jordan). Final technical report presented to the International Development Research Centre (IDRC)Canada by Royal Scientific Society (RSS), Environmental Research centre (ERC), Studies and Design Division, Amman, Jordan.

[8] Agricultural Statistics, 2002. Agricultural Statistics, Department of Statistics, Amman, Jordan. 
[9] Hamdi, M., 1996. Anaerobic digestion of olive mill wastewater. Process Biochemistry, 31, 105-110.

[10] Erg der, T. H., G ven, E., Demirer, G. N., 2000. Anaerobic treatment of OMW in batch reactors. Process Biochemistry, 36(3), 243-248.

[11] Azbar, N., 2004. A review of waste management options in olive oil production. Critical Reviews of Environmental Science and Technology, 34, 209 - 247.

[12] Boari, A., Brunetti, A., Passino, R., Rozzi, A., 1984. Anaerobic digestion of olive oil mill wastewaters. Agricultural Wastes, 10, 161-175.

[13] Ammary, B.Y., 2004. Nutrients requirements in biological industrial wastewater treatment. African Journal of Biotechnology, 3(4), 236-238

[14] Rozzi, A., Santori, M., Spinosa, L., 1984. Anaerobic digestion in Italy with special reference to treatment of olive-oil mill wastes. In Anaerobic Digestion of Sewage Sludge and Organic Agricultural Wastes, ed. A. M. Bruce, A. Koutzell-Katsiri and P. J. Newman. Elsevier Applied Scinec, London, UK, pp. 55-65.

[15] DellaGreca, M., Monaco, P., Pinto, G., Pollio, A., Previtera, L., Temussi, F., 2001. Phytotoxicity of low-molecular weight phenols from olive mill waste waters. Bull Environmental Contamination and Toxicology, 67, 352 - 359.

[16] Veerish, G. S., Kumar, P., Mehrotra I., 2005. Treatment of phenol and cresols in upflow anaerobic sludge blanket (UASB) process: a review. Water Research, 39, 154-170.

[17] Chang, Y. J., Nishio, N., Nagai, S., 1995. Characteristics of granular methanogenic sludge grown on phenol synthetic medium and methanogenic fermentation of phenolic wastewater in a UASB reactor. Journal Fermentation and Bioengineering, 79 (4), 348353.

[18] Fang, H. H. P., Liu, Y., Ke, S. Z., Zhang, T., 2004. Anaerobic degradation of phenol in wastewater at ambient temperature. Water Science and Technology, 49 (1), 95-102.

[19] Sabbah, I., Yazbak, A., Haj, J., Saliba, A., Basheeer, S., 2004b. Biomass selection for optimal anaerobic treatment of olive mill wastewater. Environmental Technology, 25,

[20] Sabbah, I., Marsook, T., Basheer, S., 2004a. The effect of pretreatment on anaerobic activity of olive mill wastewater using batch and continuous systems. Process Biochemistry, 39, 1947-1951.

[21] Field, J. A., 1989. The effect of tannic compounds on wastewater treatment. $\mathrm{PhD}$ thesis, Sub-department of Environmental Technology, Wageningen University, The Netherlands, pp. 199.

[22] Tay J., Jiang, H., Tay, S., 2004. High-rate biodegradation of phenol by aerobically grown microbial granules. Journal of Environmental and Engineering, 130 (12), 1415-1423.

[23] Lettinga, G., Hulshoff Pol, L. W., 1991. UASB process design for various types of wastewater. Water Science and Technology, 24(8), 87-107.

[24] Kortekaas, S., Vidal, G., Yan-Ling, H., Lettinga, G., Field, J., 1998. Anaerobic-aerobic treatment of toxic pulping black liquor with upfront effluent recirculation. Journal Fermentation Bioengineering, 86(1), 97-110.

[25] Sayadi S. and Ellouz R., 1993. Screening of white rot fungi for the treatment of olive mill waste-waters. Journal of Chemical Technology and Biotechnology, 57, 141-146.

[26] Jaouni, A., Sayadi, S., Vanthournhout, M., Penninckx, M., 2003. Potent fungi for decolourization of olive oil mill wastewater. Enzyme Microbiology and Technology, 33, 802-809.

[27] Dhouib, A., Aloui, F., Hamad, N., Sayadi, S., 2006. Pilot-plant treatment of olive mill wastewaters by Phanerochaete chrysosporium coupled to anaerobic digestion and ultrafiltration. Process Biochemistry, 41, 159-167in press.

[28] Al-Malah K, Azzam M., Abu-Lail N. (2000). Olive mills effluent wastewater posttreatment using activated clay. Separation and Purification Technology, 20, 225-34. 